\title{
Effects of Laparoscopic Ureterolithotomy and Simultaneous Trans-Trocar Semi-Rigid Ureteroscopy on Stone-Free Rate in the Treatment of Proximal Ureteral Stones
}

\section{Proksimal Üreter Taşlarının Tedavisinde Laparoskopik Üreterolitotomi ve Eş Zamanlı Trans-Trokar Semirijid Üreteroskopinin Taşsızlık Üzerine Etkisi}

\author{
Deniz Abat1, Adem Altunkol1, Durmuş Alparslan Demirci1, Pınar Kendigelen2, Murat Demiray3, \\ Yıldırım Bayazıt4
}

\author{
1Adana Numune Teaching and Research Hospital, Clinic of Urology, Adana, Turkey \\ 2 Afşin State Hospital, Clinic of Anesthesiology and Reanimation, Kahramanmaraş, Turkey \\ ${ }_{3}^{3}$ Afşin State Hospital, Clinic of Urology, Kahramanmaraş, Turkey \\ ${ }^{4}$ Çukurova University Faculty of Medicine, Department of Urology, Adana, Turkey
}

What's known on the subject? and What does the study add?

Effects of laparoscopic ureterolithotomy and simultaneous trans-trocar semi-rigid ureteroscopy on stone-free rate in treatment of proximal ureteral stones.

\begin{abstract}
Objective

This study presents the effects of the use of semi-rigid ureteroscopy simultaneously during laparoscopic ureterolithotomy on the stone-free rate and, the techniques used to perform laparoscopic ureterolithotomy less invasively.

\section{Materials and Methods}

Between November 2011 and July 2013, laparoscopic ureterolithotomy was performed in 19 patients with proximal ureteral stones. A history of failed shock wave lithotripsy (SWL) or semi-rigid ureteroscopy (sr-URS), presence of ureter stones $\geq 15 \mathrm{~mm}$ and/or impacted stones, or a socioeconomic status not allowing the patient to reach an advanced center for flexible ureteroscopy (f-URS) were identified as the surgical indications.

Results

Fourteen male (74\%) and five female (26\%) patients were enrolled in the study and the mean age was $36.4 \pm 15.11(15-70)$ years. The stones were located on right side in five patients (26\%) and left side in 14 patients (74\%). The mean stone size was $16.2 \pm 3.55 \mathrm{~mm}(8-22)$. The mean operation time was $138.9 \pm 29.56$ minutes $(90-200)$. The mean urethral catheter and drain removal time was $31.2 \pm 24.28$ (16-120) and $50.8 \pm 33.61$ hours (18168), respectively. There was no postoperative complication in long-term period and stone-free rate was 100\%.
\end{abstract}

Conclusion

Laparoscopic ureterolithotomy is a feasible alternative in a patient

\section{ÖZET}

Amaç

Laparoskopik üreterolitotomi sonuçlarımız ile operasyon sırasında eş zamanlı kullandığımız semi-rijid üreteroskopun taşsızlık üzerine etkisinden ve operasyonu daha az invaziv hale getirmek için uygulanan tekniklerden bahsedilmektedir.

Gereç ve Yöntem

Kasım 2011-Temmuz 2013 tarihleri arasında proksimal üreter taşı olan 19 hastaya laparoskopik üreterolitotomi uygulandı. Başarısız şok dalga litotripsi veya üreteroskopi öyküsü, taşın $15 \mathrm{~mm}$ 'den büyük ve/veya impakte olması ve hastanın fleksibıl üreteroskopi gibi operasyonların yapılabileceği başka bir merkeze gitmesine engel olan sosyo-ekonomik durumu, operasyon endikasyonu olarak belirlendi.

Bulgular

Ortalama yaşı $36,4 \pm 15,11$ yıl (15-70) olan 14'ü erkek (\%74), beşi kadın (\%26) olan toplam 19 hasta çalışmaya alındı. Taşların beşi sağ (\%26), 14 'ü sol (\%74) taraftaydı ve ortalama taş boyutu $16,2 \pm 3,55 \mathrm{~mm}(8-22)$

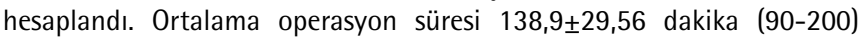
ölçüldü. Ortalama üretral kateter ve drenaj kateteri çekilme süreleri sırasıyla $31,2 \pm 24,28$ (16-120) ve $50,8 \pm 33,61$ saatti (18-168). Uzun dönemde hiçbir hastamızda komplikasyon görülmedi ve taşsızık oranı $\% 100$ olarak tespit edildi.

\section{Correspondence}

Adem Altunkol MD, Adana Numune Teaching and Research Hospital, Clinic of Urology, Adana, Turkey

Phone: +903223550101 E-mail: ademaltunkol@hotmail.com Received: 26.02.2015 Accepted: 26.02.2015 


\section{ABSTRACT}

who had previously failed minimally invasive methods and/or with large impacted proximal ureteral stone. Furthermore, to use semi-rigid ureteroscopy during the laparoscopic procedure increases the stonefree rate and prevents the need for an additional procedure in case of concurrent presence of small kidney stones.

\section{Key Words}

Laparoscopy, ureterolithotomy, ureteroscopy

\section{ÖZET}

\section{Sonuç}

Başarısız minimal invaziv tedavi öyküsü olan ve/veya büyük impakte proksimal üreter taşı olan hastalarda laparoskopik üreterolitotomi iyi bir tedavi seçeneğidir. Ayrıca laparoskopik cerrahi sırasında semirijid üreteroskopun kullanımı hem taşsızlık oranını arttırmakta hem de eş zamanlı küçük böbrek taşı olan olgularda ek bir girişim gerekliliğini ortadan kaldırmaktadır.

\section{Anahtar Kelimeler}

Laparoskopi, üreterolitotomi, üreteroskopi

\section{Introduction}

Currently, except in uncommon situations, shock wave lithotripsy (SWL), ureteroscopy (URS), percutaneous ureterolithotomy and laparoscopic surgery have replaced open surgery for the management of ureteral stones. SWL and URS are the first-line treatment options in the management of proximal ureteral stones with a low probability of spontaneous passage. Flexible ureteroscopy (f-URS) and laser lithotripsy have provided more successful results than semi-rigid URS (sr-URS) (1). Due to the high cost of the equipment involved, this method is not accessible in most medical centers. Thus, laparoscopic ureterolithotomy (LU) has become a viable alternative in most underdeveloped nations for the management of ureteral stones larger than $1 \mathrm{~cm}$ and impacted proximal ureteral stones, or after failed SWL and sr-URS (2).

Laparoscopy also enables the use of an additional approach or instrument such as laparoscopic-assisted percutaneous nephrolithotomy (PNL) or flexible nephroscope in complicated cases. In this study, we present the results of LU in patients with proximal ureteral stones. In addition, we try to demonstrate how sr-URS can be used simultaneously during LU, its effect on the stone-free rate, and how it can also be performed less invasively.

\section{Materials and Methods}

Between November 2011 and July 2013, LU was performed in 19 patients with proximal ureteral stones. A history of failed SWL or srURS, presence of ureter stones $\geq 15 \mathrm{~mm}$ and/or impacted stones, or a socio-economic status not allowing the patient to reach another center for $\mathrm{f}$-URS were identified as the surgical indications.

Informed consent for surgery was obtained through a written signed document from all patients. Preoperatively, in all patients, complete blood counts; renal and liver function tests; coagulation parameters; urinalysis; kidney-ureter-bladder (KUB) radiograph; and abdominopelvic unenhanced computed tomography (CT) were performed. The stone size was considered to be the longest measurement determined by KUB or CT. The part of the ureter up to the upper edge of the sacrum from the renal pelvis was considered as the proximal segment.

\section{Surgical Technique}

Oral laxative was given to all patients the day before the surgery and a rectal enema was carried out on the morning of the operation. Under general anesthesia, the patients were catheterized and placed in the lateral decubitus position with the side of the ureteral stone facing up. Pneumoperitoneum was created by a Veress needle, which was introduced through a pararectal incision $2 \mathrm{~cm}$ cranial to the umbilicus. A $10 \mathrm{~mm}$ trocar was introduced transperitoneally and visualization was performed with a $30^{\circ}$ lens. Two $5 \mathrm{~mm}$ ports were placed at angles convenient for working; one in the pararectal region, $4-5 \mathrm{~cm}$ cranial to the umbilicus, and one in the mid-clavicular region, $4-5 \mathrm{~cm}$ caudal to the umbilicus. The ureter was found following the medial dissection of the colon and incised using laparoscopic scissors through the protrusion that was created by the stone or on the location where the stone was felt by an atraumatic grasper. The stone was removed using a dissector and placed in a tissue and organ retrieval bag and kept inside the body until the end of the procedure. A JJ stent was placed in the ureter through the $5 \mathrm{~mm}$ port directly or with the help of a $14 \mathrm{~F}$ Amplatz renal dilator which was inserted through the $5 \mathrm{~mm}$ port. The ureteral incision was closed using a continuous suturing technique by a laparoscopic needle holder with a 3/0 polyglactin suture. The 10 $\mathrm{mm} 30^{\circ}$ lens was removed and replaced with a $2.9 \mathrm{~mm}$ lens (generally used during cystoscopy) inserted from the $5 \mathrm{~mm}$ port located $4-5 \mathrm{~cm}$ cranial to the umbilicus. The retrieval bag was removed from the 10 $\mathrm{mm}$ port or port incision. The operation was terminated after inserting a drain through the $5 \mathrm{~mm}$ caudal port. In cases when a stone, totally or partially, migrated into the kidney during the operation, or when a renal stone was present simultaneously, those stones were retrieved using a basket through the more convenient $5 \mathrm{~mm}$ caudal port using a $9.5 \mathrm{~F}$ semi-rigid ureteroscope introduced into the ureter through an incision made on the ureter (Figure 1A, 1B, and 1C).

\section{Results}

Fourteen male (74\%) and five female (26\%) patients were enrolled in the study and the mean age was $36.4 \pm 15.11$ years (15-70). Eleven (58\%) patients had a stone $\geq 15 \mathrm{~mm}$ or an impacted stone, four (21\%) patients had failed SWL, and two $(10.5 \%)$ had failed Sr-URS. Two (10.5\%) patients were operated due to their socio-economic status. The indications are summarized in Table 1. The mean stone size was calculated as $16.2 \pm 3.55 \mathrm{~mm}(8-22)$; five $(26 \%)$ stones were located on the right side and 14 (74\%) on the left side.

All operations were performed via the transperitoneal approach and none of the patients were converted to open surgery. Three ports were used in 16 (84\%) patients and a fourth port was inserted for retraction in three $(16 \%)$ patients due to difficulty in dissection. The JJ stent was inserted in $17(90 \%)$ patients, and was not placed in $2(10.5 \%)$ patients. The mean operation time for LU was calculated 
as $138.9 \pm 29.56$ minutes $(90-200)$. There were no intraoperative complications observed except that the stone migrated into the kidney in four (21\%) patients. The mean operation time was $155 \pm 32.01$ minutes (120-200) while sr-URS was performed during laparoscopic surgery. None of the patients required any blood transfusion. The mean urethral catheter and drain removal time was $31.2 \pm 24.28$ hours (16-120) and 50.8 \pm 33.61 hours (18-168), respectively. The findings are summarized in Table 2.

The JJ stent was placed on the second postoperative day in one patient (5\%) in whom JJ stent was not inserted during the laparoscopic surgery because of urinary leakage from the drain. The urethral and drainage catheters were removed on the 5th and 7th days, respectively, in this patient (Clavien $3 \mathrm{~B}$ complication). Pulmonary embolism occurred in one patient $(5 \%)$ on the second postoperative day. The patient was shifted immediately to a tertiary care medical center with an intensive care unit (ICU) (Clavien 4A complication). Upon recovery in the ICU, the patient returned to our center where percutaneous nephrolithotomy was performed in the contralateral kidney. There were no other postoperative complications among the other patients.

The stone located in the proximal ureter migrated into the kidney in four patients (21\%) during the operation. One of the stones was

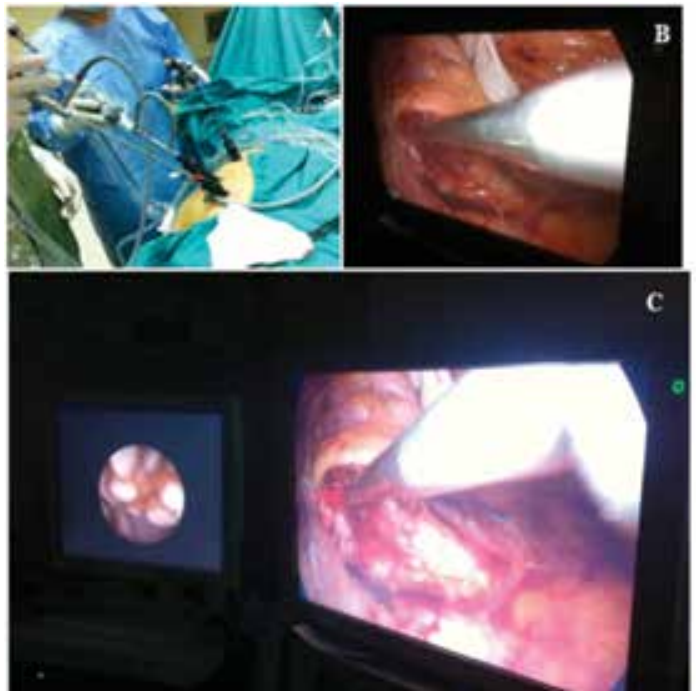

Figure 1. A: Semi-rigid ureteroscopy is placed as trans-trochar during laparoscopic surgery. B: Ureteroscope being inserted through an incision on the ureter. C: View of an intrarenal stone from the second imaging system that is connected to the ureteroscope and simultaneous intracorporeal image from the laparoscopy lens retrieved by irrigation and aspiration of serum physiologic solution. The other three stones (16\%) were retrieved by sr-URS as described.

It is notable that four of the five patients (26\%) also had kidney stone with ureteral stone at the same time. The kidney stones were located in the upper or mid pole calyx. These stones were removed by basket catheter without using pneumatic lithotripter as the stone size was $\leq 1 \mathrm{~cm}$. The kidney stone that was located in the lower pole of the calyx could not be reached in one (5\%) patient. The mean size of the stones that were removed from the kidney was calculated as $9 \mathrm{~mm}$ (8-10). There was no postoperative complication in long-term period and all ureteral stones were removed in all patients (100\%). The stone-free rate was 95\% in patients with kidney stone and ureteral stones. The $\mathrm{JJ}$ stent was placed during the operation in all patients except for the first two patients. The JJ stent was removed 2-3 weeks postoperatively under local anesthesia or sedo-analgesia. All patients were examined with KUB and/or ultrasonography at 2 months postoperatively. The mean follow-up period was $13.31 \pm 6.11$ months (3-23).

\section{Discussion}

The most appropriate method in stone management should ideally be one that is least invasive and painless, having an advantage of a short convalescence period, and provide a high stone-free rate. Furthermore, it should carry the least risk to the patient. SWL and sr-URS are minimally invasive methods and, therefore, the preferred options in the management of ureteral stones. Although SWL has a high stone-free rate in the management of proximal ureteral stones smaller than $1 \mathrm{~cm}$, its success rate is low for proximal ureteral stones larger than $1 \mathrm{~cm}(1)$. Hence, stone size is one of the main factors that can affect the success rate of SWL in this location (3). Therefore, SWL may not be a good option in the management of large impacted proximal ureteral stones because of its low stone-free and high reintervention rate.

Semi-rigid-URS is another option that has a high success rate especially when f-URS with laser is used allowing it as a first-line

Table 1. Indications of laparoscopic ureterolithotomy and number of patient

\begin{tabular}{|l||l|}
\hline Indications & Number of Patient (\%) \\
\hline \hline$>15 \mathrm{~mm}$ and/or impacted stone & $11(58 \%)$ \\
\hline Failed SWL & $4(21 \%)$ \\
\hline \hline Failed URS & $2(10,5 \%)$ \\
\hline Social Indication & $2(10,5 \%)$ \\
\hline SWL: Shock wave lithotripsy, URS: Ureteroscopy \\
\hline
\end{tabular}

Table 2. Demographic data of the patients

\begin{tabular}{|l|l||}
\hline & Mean value \pm Standard Deviation (minimum-maximum ) \\
\hline Mean Age (Year) & $36.4 \pm 15.11(15-70)$ \\
\hline \hline Sex (Woman/Man) & $5(26 \%) / 14(74 \%)$ \\
\hline Number of Port & $5(26 \%) / 14(74 \%)$ \\
\hline Mean Operation Time (minute) & Three ports were used on $16(84 \%)$ patients/Four ports were used on 3 (16\%) patients \\
\hline Mean Duration of Drainage (hour) & $138.9 \pm 29.56(90-200)$ \\
\hline Mean Duration of Urethral Catheter (hour) & $50.8 \pm 33.61(18-168)$ \\
\hline
\end{tabular}


option for ureteral stone management (4). However, the high cost remains a major disadvantage. The current literature describes the management of proximal ureteral stones using rigid or sr-URS with a pneumatic lithotripter $(2,5,6)$ or Holmium laser (7). Very different stone-free rates have been reported (62.5-90\%). To reach the stone located in the proximal ureter is sometimes not possible in a male patient with a large impacted stone due to inflammation, mucosal polyps, and ureteral kinks $(8,9)$. In addition, additional interventions may be necessary for complete stone removal if the stone itself or larger fragments migrate to the kidney. Although sr-URS has some advantages as a minimally invasive method, its disadvantages should be considered in the management of large and impacted proximal ureteral stones.

Percutaneous nephrolithotomy may be preferred when retrograde access to the stone is not possible. Although it is an effective treatment method with a high stone-free rate, excessive bleeding may require transfusion and injury to adjacent organs and colon perforation can occur, albeit rarely (10). Karami et al. have reported that there was no difference between the antegrade approach using ultrasonographyguided PNL and LU with respect to stone-free rate and complication rate in the management of proximal ureteral stones larger than 1 $\mathrm{cm}$ (11). In another study, LU, PNL, and sr-URS were compared in the management of proximal ureteral stones, and PNL was found to be more favorable than the other techniques with respect to the mean operation time and blood loss. In addition, PNL was emphatically safer and more effective than the other methods (12).

According to the updated guidelines on urolithiasis, ureterolithotomy is recommended in the management of proximal ureteral stones after failed SWL and sr-URS. It is also a management option when f-URS is not available. It is performed via the open or laparoscopic approach. However, because of the known advantages of laparoscopy versus open surgery, LU is an option in a medical center where laparoscopy could be applied (13). Although LU is not the first option as it is more invasive when compared to other techniques, LU should be considered as a second option (salvage therapy) because of its high stone-free rate.

In our clinic, LU was selected as a first option in patients with a large and impacted stone or in those unable to reach advanced medical centers and as a salvage therapy option in patients in whom other techniques failed previously. We observed that the rate of patients who underwent LU as a first option was higher. We are of the opinion that this may be associated with the large mean stone size $(16.2 \pm 3.55$ $\mathrm{mm}$ ) and the large number of patients who were unable to reach advanced medical centers where f-URS is performed.

It is important to evaluate the patient thoroughly and consider the hospital background and own laparoscopic experience before choosing management options for urolithiasis. Because laparoscopic surgery requires an adequate skill that can be gained during training, experience with LU may be offered to surgeons as a management option for large, impacted proximal ureteral stones. In a study, SWL, sr-URS and LU were compared in the management of large proximal ureteral stones and, LU was found to associate with a longer operation and recovery time compared to the other methods. Moreover, the post-operative period was more painful with LU. However, a higher success rate was found in LU (9).
Herein, we would like to elaborate the techniques we applied in LU so as to make it less invasive and to maximize the stone-free rate. As mentioned earlier, the $10 \mathrm{~mm}$ lens was removed from the $10 \mathrm{~mm}$ port and replaced with a $2.9 \mathrm{~mm}$ lens from the $5 \mathrm{~mm}$ port towards the end of the operation. This maneuver allowed us to remove the stone from the $10 \mathrm{~mm}$ port or the incision of the $10 \mathrm{~mm}$ port. Otherwise, we would have had to extend the incision of the $5 \mathrm{~mm}$ port or use a second $10 \mathrm{~mm}$ port at the beginning of the operation. A small port incision not only reduces the incidence of complications such as port site herniation and/or bleeding, but also provides a better cosmetic result. This has been confirmed in a study that examined the relationship between the length of the port site and port site complications (14). In the literature, preferred port sizes are seen as one or two $10 \mathrm{~mm}$ ports and one $5 \mathrm{~mm}$ port in addition to the 10 $\mathrm{mm}$ camera port $(15,16,17,18)$. In our technique, the operation can be completed with one $10 \mathrm{~mm}$ and two $5 \mathrm{~mm}$ ports. A $5 \mathrm{~mm}$ additional fourth port was needed for retraction in the first three of our cases $(16 \%)$. Three ports were sufficient for the rest of the patients.

Ureteral stones, especially those located proximally, can migrate into the kidney with minimal invasive techniques $(15,16,17,19,20)$. This has been managed by open surgery, f-URS, or PNL $(15,16,17,20)$. We have reported an alternative approach in the present study. We considered the cost, complication rates, and the need for an additional intervention and we simultaneously used sr-URS during LU. As mentioned, a $9.5 \mathrm{~F}$ sr-URS was introduced from the $5 \mathrm{~mm}$ port that was located more caudally and the stones were removed by using basket catheter in patients with migrated stones into the kidney and/or in those with a concomitant kidney stone. We stress the fact that it is important to be careful about the location of the $5 \mathrm{~mm}$ port that is placed more caudally. This port should be placed according to the ureter at the beginning of the operation. We could easily access the collecting system of the kidney from the ureteral incision by srURS when the $5 \mathrm{~mm}$ port was placed $4-5 \mathrm{~cm}$ below the umbilicus in the mid-clavicular line. In this aspect, the upper and mid pole calyces or pelvis could easily be reached, however, it was difficult to return to the lower calyx. The pelvis of the kidney is more inferior than the lower pole calyx in the lateral decubitus position. Therefore, stone migration towards the lower pole calyx is unlikely due to gravity. Stones migrate towards the renal pelvis or upper pole calyx rather than the lower pole calyx. All migrated stones were removed from the renal pelvis in our patients.

We performed sr-URS during LU not only in patients with migrated stones but also in patients with proximal ureteral and kidney stones. The kidney stone size in four patients was 8-10 $\mathrm{mm}$ and these stones were removed without a need for a lithotripter. Large stone sizes require crushing and may be complicated to perform by this procedure. In that case, PNL may be a more appropriate alternative method in patients with kidney stones larger than $2 \mathrm{~cm}$ and a proximal ureteral stone.

We found that the mean operation time was prolonged by $17 \mathrm{~min}$ when the additional sr-URS procedure was performed during the operation. This is an acceptable prolonged time interval when considering the high stone-free rate.

Prolonged urinary leakage was observed in one patient in whom a JJ stent was not inserted during the operation. After this case, we 
placed JJ stent in all patients. Although this is a controversial issue, in a study, the authors have suggested that JJ stent placement is not necessary except when excessive inflammation is seen or suturing is not appropriate (20). Karami et al. have reported that JJ stent placement during $\mathrm{LU}$ does not prolong operation time and prevents urinary leakage (21). In the present study, we did not observe urinary leakage in any patient when JJ stent placed into the ureter and suturing performed.

\section{Conclusion}

LU is a feasible alternative in a patient with failed SWL or sr-URS, or with a large and/or impacted proximal ureteral stone, and in a situation when the patient cannot reach an advanced center offering f-URS and laser surgery. In addition, LU offers a high stone-free rate with acceptable and manageable complications, and has some advantages over open surgery. Furthermore, in case of having to use sr-URS during the laparoscopic procedure, the operation time is not obviously increased. On the other hand, the stone-free rate is increased and, by allowing kidney stones to be removed simultaneously, it prevents the need for an additional procedure.

Ethics Committee Approval: Ethics committee approval was not obtained due to the study was disagned as retrospectively.

Informed Consent: All the patients gave written informed consent.

Concept: Deniz Abat

Design: Deniz Abat, Adem Altunkol

Data Collection or Processing: Durmuş Alparslan Demirci

Analysis or Interpretation: Adem Altunkol, Deniz Abat,

Yıldırım Bayazıt

Literature Search: Pınar Kendigelen, Murat Demiray

Writing: Deniz Abat, Adem Altunkol

Peer-review: Externally peer-reviewed.

Conflict of Interest: No conflict of interest was declared by the authors.

Financial Disclosure: The authors declared that this study has received no financial support.

\section{References}

1. Bader MJ, Eisner B, Porpiglia F, Preminger GM, Tiselius HG. Contemporary management of ureteral stones. Eur Urol 2012;61:764-772.

2. Lopes Neto AC, Korkes F, Silva JL 2nd, Amarante RD, Mattos MH, TobiasMachado M, Pompeo AC. Prospective randomized study of treatment of large proximal ureteral stones: extracorporeal shock wave lithotripsy versus ureterolithotripsy versus laparoscopy. J Urol 2012;187:164-168.

3. Preminger GM, Tiselius HG, Assimos DG, Alken $P$, Buck AC, Gallucci $M$, Knoll T, Lingeman JE, Nakada SY, Pearle MS, Sarica K, Türk C, Wolf JS Jr. Guideline forthe management of ureteral calculi. Eur Urol 2007;52:16101631.

4. Sofer M, Watterson JD, Wollin TA, Nott $L$, Razvi H, Denstedt JD. Holmium: YAG laser lithotripsy for upper urinary tract calculi in 598 patients. J Urol 2002;167:31-34.
5. Khairy-Salem $H$, el-Ghoneimy $M$, el-Atrebi M. Semirigid ureteroscopy in management of large proximal ureteral calculi: is there still a role in developing countries? Urology 2011;77:1064-1068.

6. Salem HK. A prospective randomized study comparing shock wave lithotripsy and semirigid ureteroscopy for the management of proximal ureteral calculi. Urology 2009;74:1216-1221.

7. Seitz C, Tanovic E, Kikic Z, Fajkovic H. Impact of stone size, location, composition, impaction, and hydronephrosis on the efficacy of holmium:YAG-laser ureterolithotripsy. Eur Urol 2007;52:1751-1757.

8. Degirmenci T, Gunlusoy B, Kozacioglu Z, Arslan M, Kara C, Koras O, Minareci S.. Outcomes of ureteroscopy for the management of impacted ureteral calculi with different localizations. Urology 2012;80:811-5.

9. Wu CF, Shee JJ, Lin WY, Lin CL, Chen CS. Comparison between extracorporeal shock wave lithotripsy and semirigid ureterorenoscope with holmium:YAG laser lithotripsy for treating large proximal ureteral stones. J Urol 2004;172:1899-1902.

10. Zhu Z, Xi O, Wang S, Liu J, Ye Z, Yu X, Bai J, Li C. Percutaneous nephrolithotomy for proximal ureteral calculi with severe hydronephrosis: assessment of different lithotriptors. J Endourol 2010;24:201-205.

11. Karami H, Mazloomfard MM, Lotfi B, Alizadeh A, Javanmard B. Ultrasonography-guided PNL in comparison with laparoscopic ureterolithotomy in the management of large proximal ureteral stone. Int Braz J Urol 2013;39:22-28.

12. Zhu $H$, Ye $X$, Xiao $X$, Chen $X$, Zhang 0 , Wang $H$. Retrograde, antegrade, and laparoscopic approaches to the management of large upper ureteral stones after shockwave lithotripsy failure: a four-year retrospective study. J Endourol 2014;28:100-103.

13. Almeida GL, Heldwein FL, Graziotin TM, Schmitt CS, Telöken C. Prospective trial comparing laparoscopy and opens urgery for management of impacted ureteral stones. Actas Urol Esp 2009;33:1108-1114.

14. Pemberton RJ, Tolley DA, van Velthoven RF. Prevention and management of complications in urological laparoscopic port site placement. Eur Urol 2006;50:958-968.

15. El-Moula MG, Abdallah A, El-Anany F, Abdelsalam $Y$, Abolyosr A, Abdelhameed D, Izaki $H$, Elhaggagy A, Kanayama HO. Laparoscopic ureterolithotomy: our experience with 74 cases. Int J Urol 2008;15:593597.

16. Singh V, Sinha RJ, Gupta DK, Kumar M, Akhtar A. Transperitoneal versus retroperitoneal laparoscopic ureterolithotomy: a prospective randomized comparison study. J Urol 2013;189:940-945.

17. Huri E, Basok EK, Uğurlu O, Gurbuz C, Akgül T, Ozgök Y, Bedir S. Experiences in laparoscopic removal of upper ureteral stones: multicenter analysis of cases, based on the TurkUroLap Group. J Endourol 2010;24:1279-1282.

18. Kijvikai K, Patcharatrakul S. Laparoscopic ureterolithotomy: its role and some controversial technical considerations. Int J Urol 2006;13:206-210.

19. Gaur DD, Trivedi S, Prabhudesai MR, Madhusudhana HR, Gopichand M. Laparoscopic ureterolithotomy: technical considerations and long-term follow-up. BJU Int 2002;89:339-343.

20. Tugcu V, Simsek A, Kargi T, Polat $H$, Aras B, Tasci Al. Retroperitoneal laparoendoscopic single-site ureterolithotomy versus conventional laparoscopic ureterolithotomy. Urology 2013;81:567-572.

21. Karami H, Javanmard B, Hasanzadeh-Hadah A, Mazloomfard MM, Lotfi $B$, Mohamadi R, Yaghoobi M. Is it necessary to place a Double J catheter after laparoscopic ureterolithotomy? A four-year experience. J Endourol 2012;26:1183-1186. 